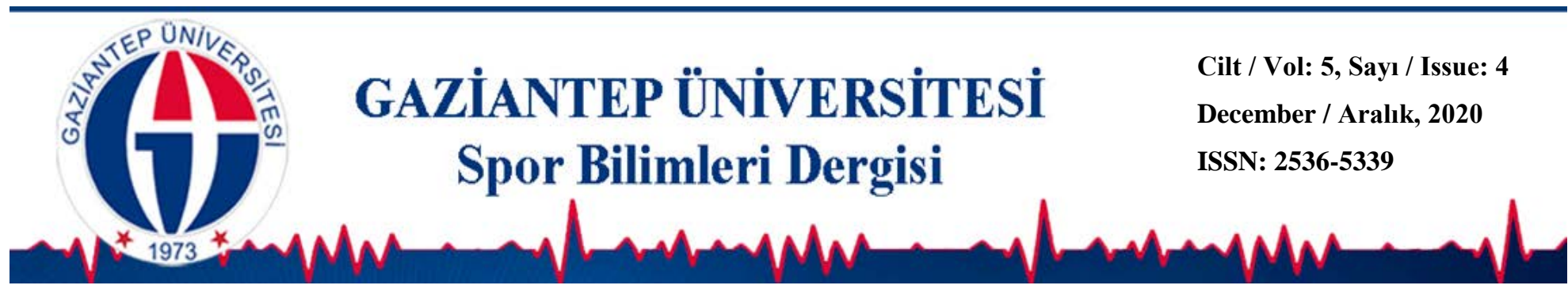

\title{
Spor Bilimleri Öğrencileri ve Diğer Bireylerde Bilinçli Tüketicilik Düzeyi İle Sürdürülebilir Tüketim Davranışlarının İncelenmesi
}

\author{
Sevim $\mathrm{KIR}^{1}$ (D) \\ Ercan POLAT ${ }^{2 *} \mathbb{1}$ \\ ${ }^{1}$ Niğde Ömer Halisdemir Üniversitesi, Spor Bilimleri Fakültesi, $N \dot{I} \breve{G} D E$ \\ ${ }^{2}$ Ağrı İbrahim Çeçen Üniversitesi, Beden Eğitimi ve Spor Yüksekokulu, $A \breve{G} R I$
}

\section{DOI: 10.31680/gaunjss.800670}

Orijinal Makale / OriginalArticle

Geliş Tarihi / Received:27.09.2020
Kabul Tarihi / Accepted:11.11.2020

\section{Öz}

Bu araştırmada spor bilimleri öğrencileri ve diğer bireylerde bilinçli tüketicilik düzeyi ile sürdürülebilir tüketim davranışlarının incelenmesi amaçlanmıştır. Araştırma 2019-2020 eğitim-öğretim yılında Niğde Ömer Halisdemir Üniversitesine öğrenim gören öğrenciler üzerinde yürütülmüştür. Araştırmanın örneklemini, öğrenciler arasından seçilen 140 kadın 160 erkek olmak üzere toplam 300 gönüllü katılımcı oluşturmuştur. Veri toplama aracı olarak anket yönteminden yararlanılmıştır. Üç bölümden oluşan anketin birinci bölümünde Kişisel Bilgi Formu, ikinci bölümünde Doğan, Bulut ve Çımrın (2015) tarafından geliştirilen Sürdürülebilir Tüketim Davranışları Ölçeği ve son bölümde ise Sağlam (2010) tarafından geliştirilen Bilinçli Tüketicilik Düzeyi Ölçeği kullanılmıştır. Verilerin analizinde tanımlayıcı istatistiklerin yanı sıra, ikili değişkenler arası karşılaştırmalarda $t$ testi, ilişkisel incelemelerde korelasyon analizi ve gruplara ait korelasyonel karşılaştırmalarda ise $z$ skoru hesaplanarak veriler çözümlenmiştir. Analiz sonucunda sürdürülebilir tüketim davranışları ölçeğinin çevre duyarlılığı ve ihtiyaç dışı satın alma boyutlarında; sporculuk durumu, cinsiyet ve aktif spor yapma durumu değişkenlerinde farklılıklar görülmüştür. İki ölçek alt boyutları arasında pozitif ve negatif yönde ilişkiler bulunmuştur. Sonuç olarak bilinçli tüketicilik düzeyi sürdürülebilir tüketim davranışlarını etkilediği söylenebilir.

Anahtar Kelimeler: Bilinçli Tüketicilik Düzeyi, Sürdürülebilir Tüketim Davranışı, Spor Bilimleri, Öğrenci

\section{Investigation of Conscious Consumerism Level and Sustainable Consumption Behaviors in Sports Science Students and Other Individuals}

\begin{abstract}
In this study, it is aimed to examine the level of conscious consumerism and sustainable consumption behavior in sports science students and other individuals. The research was conducted on students attending Nigde Omer Halisdemir University in the 2019-2020 academic year. The sample of the study consisted of a total of 300 volunteer participants, 140 women and 160 men selected from among the students. Survey method was used as a data collection tool. The questionnaire consists of three parts. In the first part, the Personal Information Form, in the second part, the Sustainable Consumption Behavior Scale developed by Doğan, Bulut and Çımrın (2015), and the Scale for the Level of Conscious Consumerism developed by Sağlam (2010) were used in the last section. In the analysis of the data, besides descriptive statistics, the data were analyzed by calculating the t-test for comparisons between binary variables, correlation analysis in relational studies and the $z$ score for correlational comparisons of the groups. As a result of the analysis, in the environmental awareness and out-ofneed purchasing dimensions of the scale of sustainable consumption behaviors; differences were observed in the variables of sportsmanship, gender and active sports status. Positive and negative relationships were found between the two scales sub-dimensions. As a result, it can be said that conscious consumerism level affects sustainable consumption behaviors.
\end{abstract}

Keywords: Conscious Consumer Level, Sustainable Consumption Behavior, Sports Sciences, Student

\footnotetext{
* Sorumlu Yazar: Ercan POLAT
}

e-mail: ercihanpolat@hotmail.com 


\section{Giriş}

İnsanlığın var olmasıyla beraber başlayan tüketim süreci yaşamın devamlılığı için gerekli bir araç durumunda iken, modern dünya koşullarında önemli bir amaç haline gelmiştir. Tüketim; insanların intiyaç ve isteklerinin karşılanması amacıyla insanlar tarafından üretilen mal ve hizmetlerin, yine insanlar tarafından kullanılması olarak tanımlanır. Tüketim temel intiyaçlar tamamlandıktan sonra konfor amacıyla yapılmaya başlanmışır (Çelik, 2013).

Tüketim, sadece ticari anlamda değil aynı zamanda sosyal olarak da değerlendirilmekle birlikte, gelişen ve değişen dünyada yenilenen gereksinimlere, popüler kavramlara, tanınmış markalara, pazarın durumuna ve tüketicinin beklentilerine göre yeniden şekillenmektedir (Hümeriç ve Baban, 2012). Bireylerin sahip oldukları demografik özellikler ve özellikle de gelir düzeyi (yaş, cinsiyet, eğitim durumları vs.) tüketim kararlarını etkilemektedir.

Bireylerin sürekli tüketim halinde olmaları bilinçli tüketici eğitimine olan ihtiyacı ortaya koymaktadır. İnsanların temel gereksinimlerini ön planda tutarak intiyaçları kadar tüketmeleri, gelir ve giderleri arasındaki denge oranını korumaları, sahip oldukları kaynakların verimli kullanılması, tüketimin bilinçli olduğunu gösterir (Gülmez, 2006). Bilinçli tüketim birey için olduğu kadar ülke ekonomisi için de önemli bir husustur.

Sürdürülebilirlik, kavramı incelendiğinde ise birçok farklı tanımı bulunmakla birlikte, çok geniş bir alanı kapsadığı söylenebilir. Sürdürülebilirlik kelime anlamı olarak; üretkenlik ve çeşitliliğin devamlıı̆ğ sağlanırken, kalıcı olabilme etkisini korumak olarak tanımlanır (Şart, 2019). Temelinde, gelecek kuşaklara her bakımdan yaşanabilir bir dünya bırakma fikri bulunmaktadır.

Sürdürülebilirlik kavramının tüketim alanındaki boyutu "sürdürülebilir tüketim" düşüncesidir. Son yıllarda özellikle gelişmiş ülkelerde artan tüketim düzeyinin, dünya kaynaklarının tükenme tehlikesi olduğunu ortaya çıkararak, tüketimin çevre üzerindeki etkilerinin incelenmesi ve tüketim davranışlarının sürdürülebilir tüketim davranışlarına dönüştürülmesi fikri dile getirilmiştir (Karalar ve Kiracı, 2011). Sürdürülebilir tüketim çerçevesinde üretimin desteklenmesi, çevresel ve sosyal intiyaçlar için uygun uzun süreli ekonomik büyümenin sağlanmasına yardım eder (OECD, 2008). Sürdürülebilir tüketim, dünya kaynaklarının sürdürülebilirlik sınırları 
Polat, E. ve Kır, S. (2020). Spor Bilimleri Öğrencileri ve Diğer Bireylerde Bilinçli Tüketicilik Düzeyi İle Sürdürülebilir Tüketim Davranışlarının İncelenmesi. Gaziantep Üniversitesi Spor Bilimleri Dergisi, 5(4), 468485.

çerçevesinde kullanılması ve doğal yaşam alanlarına verilen zararları en aza indirmesini planlayan tüketim biçimidir (Bayazıt Hayta, 2009).

Sürdürülebilir tüketim; ekonomi, sosyoloji ve çevre gibi çeşitli boyutları içinde barındıran bir kavramdır. Bu yaklaşım çevre dengesinin korunması, modern pazarlama ekonomilerinin doğru ve verimli kullanılması, sürdürülebilirlik kapsamında üretim teknolojilerinin geliştirilmesi gibi pek çok unsuru içermektedir (Aksu, 2014).

Literatürde yapılan taramalarda bilinçli tüketicilik ve sürdürülebilir tüketim davranışları kavramlarının farklı boyutlarda ele alındığı birçok çalışma görülmektedir. Örnek olması amacıyla, bilinçli tüketicilik kapsamında literatürde; Robinson ve Smith 2003; Malbeleği 2011; Uyanık 2015; Polat ve Ünişen 2016; Alimcan 2018 ve Çelebi 2019 tarafından yapılan araştırmalara; tüketici davranışlarıyla ilgili olarak; Akyüz 2009; Burucuoğlu 2016; Aysel 2018; Narman 2018 ve Üler 2018; tarafından yapılan çalışmalara; sürdürülebilir tüketim kapsamında ise literatürde; Aksu 2014; Chang 2017; Hoq 2017; Diksaç 2019; Garip 2019; Polat ve ark., 2019 ve Saba 2019 tarafından yapılan araştırmalara rastlanmıştır. Ancak yapılan taramalarda bilinçli tüketicilik ve sürdürülebilir tüketim davranışları, spor bilimleri ve diğer bölümlerle doğrudan bağdaşmış bir çalışmayla karşılaşılmamıştır.

Bu açıklamalar ışığında bilinçli tüketicilik ve sürdürülebilir tüketim davranışları kavramlarını spor bilimleri ve diğer bölümler bağlamında birlikte ele almak önem arz etmektedir. Ayrıca artan tüketim düzeyinin tüketimin etkenlerinin incelenmesini gerekli kılmıştır. Bu konuda yapılacak diğer çalışmalara katkıda bulunacağı düşünülmektedir. Bu sebeple çalışmanın amacı; spor bilimleri öğrencileri ve diğer bireylerde bilinçli tüketicilik düzeyi ile sürdürülebilir tüketim davranışlarının incelenmesidir.

\section{Yöntem}

\section{Araştırmanın Modeli}

Araştırmanın modeli olarak karşılaştırmalı ilişkisel tarama modeli kullanılmıştır. İlişkisel tarama modeli; iki veya daha fazla değişken arasında birlikte değişimin derecesini veya varlığını ortaya koymayı amaçlayan bir araştırma modelidir (Karasar, 2016). 


\section{Evren ve Örneklem}

$\mathrm{Bu}$ araştırmada çalışma evreni kullanılmıştır. Çalışma evreni ulaşılabilen evrendir. Araştırmanın evrenini 2019-2020 eğitim yılında Niğde Ömer Halisdemir Üniversitesine devam eden öğrenciler oluşturmaktadır. Araştırmanın örneklem seçim yöntemi olarak uygun örnekleme kullanılmıştır. Bu doğrultuda spor bilimleri ve diğer bölümler olmak üzere üniversiteye devam eden 140'ı kadın 160'ı erkek toplam 300 gönüllü öğrenci katııım göstermiştir.

\section{Veri Toplama Aracı}

Veri toplama aracı olarak anket yönteminden yararlanılmıştır. Üç bölümden oluşan anketin birinci bölümünde Kişisel Bilgi Formu, ikinci bölümünde Sürdürülebilir Tüketim Davranışları Ölçeği, üçüncü bölümünde ise Bilinçli Tüketicilik Düzeyi Ölçeği kullanılmıştır.

Kişisel Bilgi Formu: Katılımcıların kişisel bilgilerine ulaşmak için hazırlanmış toplamda 9 maddeden oluşan değişkenlere yer verilmiştir. Bu değişkenler; yaş, cinsiyet, akademik başarı ortalaması, eğitim görülen fakülte/yüksekokul, aylık kişisel gelir, lisanslı sporculuk durumu, rekreatif amaçlı spor yapma durumu, spor yapma süreleri, doğanın korunmasına karşı duyarlılık düzeyidir.

Sürdürülebilir Tüketim Davranışları Ölçeği: Doğan, Bulut ve Çımrın (2015) tarafından geliştirilen Sürdürülebilir Tüketim Davranışları Ölçeği toplam 17 maddeden ve 4 alt boyuttan meydana gelmektedir. Ölçeğin alt boyutlarından Çevre Duyarlıı̆ı olarak adlandırılan ilk boyut toplam 5 maddeden oluşmaktadır (1. ve 5. maddeler arası). İhtiyaç Dışı Satın Alma olarak adlandırılan ikinci boyut toplam 5 maddeden oluşmaktadır (6. ve 10. maddeler arası). Tasarruf olarak adlandırılan üçüncü boyut toplam 4 maddeden oluşmaktadır (11. ve 14. maddeler arası). Yeniden Kullanabilirlik olarak adlandırılan dördüncü boyut ise (15. ve 17. maddeler arası) toplam 3 maddeden oluşmaktadır. 5'li likert tipi dereceleme kullanılan ölçek "Hiçbir Zaman (1)", "Çok Seyrek (2)", "Bazen (3)", "Genellikle (4), "Her Zaman (5)" şeklinde puanlanmaktadır. Çevre Duyarıı̆ı̆ı, Tasarruf ve Yeniden Kullanılabilirlik alt boyutlarında puan arttıkça sürdürülebilir tüketim davranışı da o denli yükselmektedir. İhtiyaç Dışı Satın Alma boyutunda ise durum tam tersidir. Bu boyutun maddelerine verilen puan azaldıkça tüketimin sürdürülebilirliği artmaktadır (Doğan ve ark., 2015). Ölçek alt boyutlarının güvenirlik değerleri tablo 1 'de verilmiştir. 
Polat, E. ve Kır, S. (2020). Spor Bilimleri Öğrencileri ve Diğer Bireylerde Bilinçli Tüketicilik Düzeyi İle Sürdürülebilir Tüketim Davranışlarının İncelenmesi. Gaziantep Üniversitesi Spor Bilimleri Dergisi, 5(4), 468485.

Tablo 1. Sürdürülebilir Tüketim Davranışları Ölçeği Alt Boyutları Güvenilirlik Analizi

\begin{tabular}{lll}
\hline Alt boyutlar & Madde sayısı & $\alpha$ \\
\hline Çevre duyarı̆ı̆ı & 5 Madde & 0,80 \\
İhtiyaç dışı satın alma & 5 Madde & 0,78 \\
Tasarruf & 4 Madde & 0,54 \\
Yeniden kullanabilirlik & 3 Madde & 0,59
\end{tabular}

Bilinçli Tüketicilik Düzeyi Ölçeği: Sağlam (2010) tarafından geliştirilen Bilinçli Tüketicilik Düzeyi Ölçeği: Tüketici Sorumluluğu Bilinci (1. ve 8. Maddeler arası), Kalite Bilinci (9. ve 13. Maddeler arası), Bütçe-Fiyat Bilinci (14. ve 19. Maddeler arası) olmak üzere 3 alt boyuttan oluşan toplam 19 maddelik bir ölçme aracıdır. 4'lü likert tipi dereceleme kullanılan ölçek "Hiçbir Zaman (1)", "Ara Sıra (2)", "Çoğu Zaman (3)", "Her Zaman (4)" şeklinde puanlanmaktadır. 7. ve 18. Maddeler bilinçli tüketicilikle ilgili olumsuz olarak değerlendirildiği için bu maddelerin puanlamaları tersine çevrilmiştir. Bu maddeler için dereceleme "Hiçbir Zaman (4)", "Ara Sıra (3)", "Çoğu Zaman (2)", "Her Zaman (1)" olacak şekilde puanlandırılmıştır. Bu çalışma kapsamında ölçeklere ilişkin güvenirlik kat sayıları aşağıdaki tabloda verilmiştir.

Tablo 2. Bilinçli Tüketicilik Düzeyi Ölçeği Alt Boyut Güvenirlik Analizi

\begin{tabular}{lll}
\hline Alt boyutlar & Madde Sayısı & $\alpha$ \\
\hline Tüketici sorumluluğu bilinci & 8 Madde & 0,60 \\
Kalite bilinci & 5 Madde & 0,67 \\
Bütçe- fiyat bilinci & 6 Madde & 0,66 \\
\hline
\end{tabular}

\section{Verilerin Toplanması}

Anketler yüz yüze görüşme yöntemi kullanılarak katılımcılara ulaştırılmıştır. Ayrıca anketin dağıtımında eğitilmiş yardımcılar kullanıımışıı. Bu yardımcılara anketin nasıl dağıtılacağı ve doldurulacağı konusunda kısa bir eğitim verilmiş ve sonrasında uygulamaya geçilmiştir. Araştırmaya katııımda gönüllülük esas alınmıştır. Gönüllü olmayan kişiler çalışmaya dâhil edilmemiştir. Toplam 330 anket dağıtılıış bunlardan 300 tanesi doğru doldurulmuş olarak kabul edilmiş ve değerlendirmeye alınmıştır.

\section{Verilerin analizi}

Elde edilen veriler SPSS 21.0 paket programından yararlanılarak istatistiksel analizler yapıımışıı. Araştırma verilerinin analizinde yüzde (\%), frekans dağılımları ve ortalama-yaygınlık ölçülerine ilişkin tanımlayıcı istatistikler yapılmıştır. Bağımlı ve 
Polat, E. ve Kır, S. (2020). Spor Bilimleri Öğrencileri ve Diğer Bireylerde Bilinçli Tüketicilik Düzeyi İle Sürdürülebilir Tüketim Davranışlarının İncelenmesi. Gaziantep Üniversitesi Spor Bilimleri Dergisi, 5(4), 468485.

bağımsız değişkenler arası normallik dağılımları incelenmiş (çarpıklık ve basıklık \pm 1 aralığında) ve parametrik test kararı verilmiştir. Demografik değişkenler ve ölçeklerin alt boyutları arasındaki ilişki için $t$ Testi uygulanmıştır. Illişki karşılaştırmalarında Pearson Korelasyon Analizi kullanılmıştır. Ayrıca gruplara ayrılarak yapılan ikili korelasyon analizinde ortaya çıkan $r$ değerlerinin karşılaştırıması için $Z$ skoru hesaplanmış ve gruplar arasındaki farklılıklar incelenmiştir.

\section{Bulgular}

Tablo 3. Tanımlayıcı İstatistikler - Yüzde ve Frekans ile Ortalama ve Yaygınlık

\begin{tabular}{|c|c|c|c|c|c|c|c|c|}
\hline Değişken & Grup & $f$ & $\%$ & Top. & $\bar{x}$ & $\mathbf{S}$ & En az & En çok \\
\hline Cinsiyet & $\begin{array}{l}\text { Kadın } \\
\text { Erkek }\end{array}$ & $\begin{array}{l}140 \\
160\end{array}$ & $\begin{array}{l}46,7 \\
53,3\end{array}$ & 300 & & & & \\
\hline Bölüm & $\begin{array}{l}\text { Spor Bilimleri } \\
\text { Diğer Bölümler }\end{array}$ & $\begin{array}{l}147 \\
153 \\
\end{array}$ & $\begin{array}{l}49,0 \\
51,0 \\
\end{array}$ & 300 & & & & \\
\hline $\begin{array}{l}\text { Lisanslı sporculuk } \\
\text { durumu }\end{array}$ & $\begin{array}{l}\text { Evet } \\
\text { Hayır }\end{array}$ & $\begin{array}{l}57 \\
243\end{array}$ & $\begin{array}{l}19,0 \\
81,0\end{array}$ & 300 & & & & \\
\hline $\begin{array}{l}\text { Rekreatif amaçı } \\
\text { spora katıım }\end{array}$ & $\begin{array}{l}\text { Evet } \\
\text { Hayır }\end{array}$ & $\begin{array}{l}161 \\
139\end{array}$ & $\begin{array}{l}53,7 \\
46,3\end{array}$ & 300 & & & & \\
\hline Yaş & & & & 300 & 21,06 & 2,41 & 2,00 & 37,00 \\
\hline Başarı ortalaması & & & & 300 & 2,62 & 0,69 & ,00 & 5,53 \\
\hline Gelir düzeyi & & & & 300 & 796,86 & 742,06 & 100,00 & 8000,0 \\
\hline $\begin{array}{l}\text { Spor yapma } \\
\text { süresi }\end{array}$ & & & & 300 & 20,83 & 33,28 & ,00 & 168,00 \\
\hline Doğa duyarlılığı & & & & 300 & 8,14 & 1,60 & 2,00 & 10,00 \\
\hline $\begin{array}{l}\text { Sürdürülebilir tük€ } \\
\text { Çevre duyarlıı̆̆ı } \\
\text { Ihtiyaç dışı satın alr } \\
\text { Tasarruf } \\
\text { Yeniden kullanabilir }\end{array}$ & $\begin{array}{l}\text { tim ölçeği } \\
\text { lik }\end{array}$ & & & $\begin{array}{l}300 \\
300 \\
300 \\
300\end{array}$ & $\begin{array}{l}3,03 \\
2,42 \\
3,51 \\
3,17\end{array}$ & $\begin{array}{l}0,80 \\
0,90 \\
1,23 \\
0,90\end{array}$ & $\begin{array}{l}1,00 \\
1,00 \\
1,00 \\
1,00\end{array}$ & $\begin{array}{l}5,00 \\
5,00 \\
16,00 \\
5,00\end{array}$ \\
\hline $\begin{array}{l}\text { Bilinçli tüketicilik } \\
\text { Tüketici sorumluluğ } \\
\text { Kalite bilinci } \\
\text { Bütçe - fiyat bilinci }\end{array}$ & $\begin{array}{l}\text { jlçeği } \\
\text { ubilinci }\end{array}$ & & & $\begin{array}{l}299 \\
299 \\
300\end{array}$ & $\begin{array}{l}2,83 \\
3,04 \\
3,31\end{array}$ & $\begin{array}{l}0,53 \\
0,55 \\
0,51\end{array}$ & $\begin{array}{l}1,13 \\
1,00 \\
1,50\end{array}$ & $\begin{array}{l}4,75 \\
4,00 \\
4,00\end{array}$ \\
\hline
\end{tabular}

Tablo 3 incelendiğinde 21,06 yaş ortalamasına sahip katıımcıların \%46,7'si kadın (n=140), \%49,0'ı (n=147) Spor bilimleri alanında eğitim gördüğü belirlenmiştir. Katııımcıların \%19,0'ı ( $n=57$ ) lisanslı olarak spor yaptığını belirtirken \%53,7'si $(n=161)$ rekreatif amaçlı fiziksel aktivitelere katıım gerçekleştirdiğini belirtmiştir. Ölçek alt boyutları incelendiğinde; Sürdürülebilir tüketim ölçeğinin alt boyutlarında en yüksek ortalamanın tasarruf alt boyutunda $(3,51 \pm 1,23)$, en düşük ortalamanın ise 
Polat, E. ve Kır, S. (2020). Spor Bilimleri Öğrencileri ve Diğer Bireylerde Bilinçli Tüketicilik Düzeyi İle Sürdürülebilir Tüketim Davranışlarının İncelenmesi. Gaziantep Üniversitesi Spor Bilimleri Dergisi, 5(4), 468485.

intiyaç dışı satın alma alt boyutunda $(2,42 \pm 0,90)$ olduğu görülmüştür. Bilinçli tüketicilik ölçeği alt boyutlarında ise en yüksek ortalamanın bütçe-fiyat bilinci alt boyutunda $(3,31 \pm 0,51)$, en düşük ortalamanın ise tüketici sorumluluğu bilinci alt boyutunda $(2,83 \pm 0,53)$ olduğu görülmüştür.

Tablo 4.Cinsiyete Göre Sürdürülebilir Tüketim Davranışları Ve Bilinçli Tüketicilik Düzeyi Alt Boyutları

\begin{tabular}{|c|c|c|c|c|c|c|c|c|}
\hline \multicolumn{2}{|c|}{ Alt boyutlar } & Cinsiyet & $\mathbf{N}$ & $\bar{x}$ & $\mathbf{s}$ & sd & $\mathbf{t}$ & $\mathbf{p}$ \\
\hline \multirow{8}{*}{ 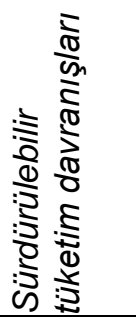 } & Cevre duyarlıı̆̆̆| & Kadın & 140 & 3,01 & 0,75 & \multirow{2}{*}{298} & \multirow{2}{*}{$-0,37$} & \multirow{2}{*}{0,71} \\
\hline & çevre duyarming & Erkek & 160 & 3,05 & 0,84 & & & \\
\hline & İhtiyaç dışı satın & Kadın & 140 & 2,60 & 0,86 & \multirow{2}{*}{298} & \multirow{2}{*}{3,16} & \multirow{2}{*}{0,00} \\
\hline & alma & Erkek & 160 & 2,27 & 0,91 & & & \\
\hline & Tasarruf & Kadın & 140 & 3,47 & 0,99 & \multirow{2}{*}{298} & \multirow{2}{*}{$-0,45$} & \multirow{2}{*}{0,65} \\
\hline & & Erkek & 160 & 3,53 & 1,40 & & & \\
\hline & Yenide & Kadın & 140 & 3,22 & 0,90 & \multirow{2}{*}{298} & \multirow{2}{*}{0,87} & \multirow{2}{*}{0,38} \\
\hline & kullanabilirlik & Erkek & 160 & 3,13 & 0,90 & & & \\
\hline \multirow{5}{*}{ 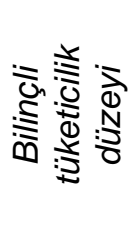 } & Tüketici sorumluluğu & Kadın & 140 & 2,85 & 0,47 & \multirow{2}{*}{297} & \multirow{2}{*}{0,41} & \multirow{2}{*}{0,68} \\
\hline & bilinci & Erkek & 159 & 2,82 & 0,57 & & & \\
\hline & Kalite bilinci & Kadın & 140 & 3,08 & 0,52 & \multirow{2}{*}{297} & \multirow{2}{*}{1,29} & \multirow{2}{*}{0,20} \\
\hline & & Erkek & 159 & 3,00 & 0,57 & & & \\
\hline & Bütçe-fiyat bilinci & Kadın & 140 & 3,34 & 0,52 & 298 & 0,97 & 0,33 \\
\hline
\end{tabular}

Tablo 4'de katılımcıların cinsiyetlerine göre sürdürülebilir tüketim davranışları ölçeği ve bilinçli tüketicilik düzeyi ölçeği alt boyutlarına ilişkin karşılaştırma sonuçları verilmiştir. Tablo incelendiğinde ölçeklerin alt boyutlarından sadece sürdürülebilir tüketim davranışları ölçeğinin ihtiyaç dışı satın alma alt boyutunun kadınların lehine anlamlı farklılığın $(p<0,05)$ olduğu görülmektedir. Diğer boyutlarda anlamlı fark yoktur

Tablo 5. Bölüme Göre Sürdürülebilir Tüketim Davranışları ve Bilinçli Tüketicilik Düzeyi Alt Boyutları

\begin{tabular}{|c|c|c|c|c|c|c|c|c|}
\hline \multicolumn{2}{|c|}{ Alt boyutlar } & Bölüm & $\mathbf{N}$ & $\bar{x}$ & S & sd & $t$ & p \\
\hline \multirow{4}{*}{ 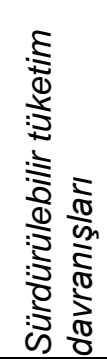 } & Çevre duyarlıığı & $\begin{array}{l}\text { Spor Bilimleri } \\
\text { Diğer bölümler }\end{array}$ & $\begin{array}{l}147 \\
153\end{array}$ & $\begin{array}{l}3,08 \\
2,98\end{array}$ & $\begin{array}{l}0,82 \\
0,78\end{array}$ & 298 & 1,01 & 0,27 \\
\hline & $\begin{array}{l}\text { İhtiyaç dışı satın } \\
\text { alma }\end{array}$ & $\begin{array}{l}\text { Spor Bilimleri } \\
\text { Diğer bölümler }\end{array}$ & $\begin{array}{l}147 \\
153\end{array}$ & $\begin{array}{l}2,44 \\
2,40\end{array}$ & $\begin{array}{l}0,86 \\
0,94\end{array}$ & 298 & 0,45 & 0,65 \\
\hline & Tasarruf & $\begin{array}{l}\text { Spor Bilimleri } \\
\text { Diğer bölümler }\end{array}$ & $\begin{array}{l}147 \\
153\end{array}$ & $\begin{array}{l}3,45 \\
3,56\end{array}$ & $\begin{array}{l}1,48 \\
0,93\end{array}$ & 298 & $-0,76$ & 0,45 \\
\hline & $\begin{array}{l}\text { Yeniden } \\
\text { kullanabilirlik }\end{array}$ & $\begin{array}{l}\text { Spor Bilimleri } \\
\text { Diğer bölümler }\end{array}$ & $\begin{array}{l}147 \\
153\end{array}$ & $\begin{array}{l}3,12 \\
3,22\end{array}$ & $\begin{array}{l}1,01 \\
0,77\end{array}$ & 298 & $-0,96$ & 0,34 \\
\hline \multirow{3}{*}{ 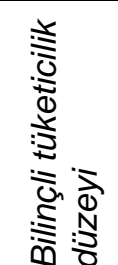 } & $\begin{array}{l}\text { Tüketici } \\
\text { sorumluluğu bilinci }\end{array}$ & $\begin{array}{l}\text { Spor Bilimleri } \\
\text { Diğer bölümler }\end{array}$ & $\begin{array}{l}147 \\
152\end{array}$ & $\begin{array}{l}2,85 \\
2,82\end{array}$ & $\begin{array}{l}0,54 \\
0,52\end{array}$ & 297 & 0,58 & 0,56 \\
\hline & Kalite bilinci & $\begin{array}{l}\text { Spor Bilimleri } \\
\text { Diğer bölümler }\end{array}$ & $\begin{array}{l}147 \\
153\end{array}$ & $\begin{array}{l}3,01 \\
3,07\end{array}$ & $\begin{array}{l}0,58 \\
0,51\end{array}$ & 297 & $-1,00$ & 0,31 \\
\hline & Bütçe-fiyat bilinci & $\begin{array}{l}\text { Spor Bilimleri } \\
\text { Diğer bölümler }\end{array}$ & $\begin{array}{l}147 \\
153\end{array}$ & $\begin{array}{l}3,29 \\
3,33\end{array}$ & $\begin{array}{l}0,53 \\
0,50\end{array}$ & 298 & $-0,65$ & 0,51 \\
\hline
\end{tabular}


Polat, E. ve Kır, S. (2020). Spor Bilimleri Öğrencileri ve Diğer Bireylerde Bilinçli Tüketicilik Düzeyi İle Sürdürülebilir Tüketim Davranışlarının İncelenmesi. Gaziantep Üniversitesi Spor Bilimleri Dergisi, 5(4), 468485.

Tablo 5'de katıımcıların bölümlerine göre sürdürülebilir tüketim davranışları ölçeği ve bilinçli tüketicilik düzeyi ölçeği alt boyutları arasındaki farklııklar incelenmiştir. Tablo incelendiğinde alt boyutlar ve bölümler arasında anlamlı bir fark $(p>0,05)$ olmadığı belirlenmiştir.

Tablo 6. Lisansıı Sporculuk Durumuna Göre Sürdürülebilir Tüketim Davranışları ve Bilinçli Tüketicilik Düzeyi Alt Boyutları

\begin{tabular}{|c|c|c|c|c|c|c|c|c|}
\hline & Alt boyutlar & $\begin{array}{l}\text { Lisanslı } \\
\text { Sporcu }\end{array}$ & $\mathbf{N}$ & $\bar{x}$ & $\mathbf{s}$ & sd & $\mathbf{t}$ & $\mathbf{p}$ \\
\hline & Çevre duyarlılığı & Evet & 57 & 3,22 & 0,76 & 298 & 1,98 & 0,05 \\
\hline$\stackrel{\omega_{n}}{\Sigma}$ & & $\begin{array}{l}\text { Hayır } \\
\text { Evet }\end{array}$ & $\begin{array}{c}243 \\
57\end{array}$ & $\begin{array}{l}2,99 \\
\mathbf{2 , 6 5}\end{array}$ & $\begin{array}{l}0,80 \\
1,04\end{array}$ & & & \\
\hline$\equiv$ & İhtiyaç dışı satın alma & Hayır & 243 & 2,37 & $\begin{array}{l}1,04 \\
0,87\end{array}$ & 298 & 2,11 & 0,04 \\
\hline$\frac{0}{0} \frac{\pi}{8}$ & Tasarruf & Evet & 57 & 3,74 & 1,91 & 298 & & 012 \\
\hline$\sqrt[5]{5} \cdot 5$ & l asarrur & Hayır & 243 & 3,45 & 1,01 & 298 & 1,55 & 0,12 \\
\hline : & Yeniden kullanabilirlik & Evet & 57 & 3,32 & $\begin{array}{l}0,97 \\
0,88\end{array}$ & 298 & 1,31 & 0,19 \\
\hline & Tüketici sorumluluğu & Evet & 57 & 2,81 & 0,47 & & & \\
\hline & bilinci & Hayır & 243 & 2,23 & 0,54 & 297 & $-0,33$ & 0,75 \\
\hline & Kalite hilinci & Evet & 56 & 3,09 & 0,53 & 297 & 080 & 012 \\
\hline$=\frac{0}{7}$ & & Hayır & 243 & 3,02 & 0,55 & 291 & 0,00 & 0,43 \\
\hline$\stackrel{N}{*} \stackrel{N}{=}$ & Bütçe-fiyat bilinci & Evet & 57 & 3,21 & 0,49 & 298 & $-1,70$ & 0,09 \\
\hline & & Hayır & 243 & 3,34 & 0,51 & & & \\
\hline
\end{tabular}

Tablo 6'da katılımcıların lisanslı olarak spor yapma durumuna göre sürdürülebilir tüketim davranışları ölçeği ve bilinçli tüketicilik düzeyi ölçeği alt boyutlarına ilişkin karşılaşııma sonuçları verilmiştir. Tabloya göre sürdürülebilir tüketim davranışları ölçeğinin çevre duyarılıı̆ı ve intiyaç dışı satın alma alt boyutlarında anlamlı farklılıkların $(p<0,05)$ olduğu görülmektedir. Bu farklııkların lisanslı sporcular lehine olduğu görülmektedir. Diğer alt boyutlarda ise anlamlı farklılık bulunmamaktadır.

Tablo 7. Rekreatif Amaçlı Spora Katılım Durumuna Göre Sürdürülebilir Tüketim Davranışları ve Bilinçli Tüketicilik Düzeyi Alt Boyutları

\begin{tabular}{|c|c|c|c|c|c|c|c|c|}
\hline & Alt boyutlar & $\begin{array}{l}\text { Rekreatif } \\
\text { Spor }\end{array}$ & $\mathbf{N}$ & $\bar{x}$ & $\mathbf{s}$ & sd & $\mathbf{t}$ & $\mathbf{p}$ \\
\hline \multirow{6}{*}{ 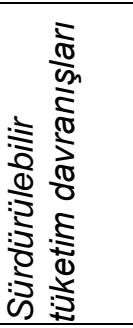 } & Çevre duyarlıığı & Evet & 161 & 3,11 & $\begin{array}{l}0,81 \\
078\end{array}$ & 298 & 1,91 & 0,06 \\
\hline & İhtiyaç dışı satın & $\begin{array}{l}\text { Haylr } \\
\text { Evet }\end{array}$ & $\begin{array}{l}139 \\
161\end{array}$ & $\begin{array}{l}2,94 \\
2,32\end{array}$ & $\begin{array}{l}0,18 \\
0,86\end{array}$ & \multirow[b]{2}{*}{298} & \multirow[b]{2}{*}{$-2,01$} & \multirow[b]{2}{*}{0,05} \\
\hline & alma & Hayır & 139 & 2,54 & 0,94 & & & \\
\hline & Tasarruf & Evet & 161 & 3,58 & 1,42 & \multirow[t]{2}{*}{298} & 1,11 & \multirow[t]{2}{*}{0,27} \\
\hline & Yeniden & $\begin{array}{l}\text { Hayır } \\
\text { Evet }\end{array}$ & $\begin{array}{l}139 \\
161\end{array}$ & $\begin{array}{l}3,42 \\
3,16\end{array}$ & 0,97 & & \multirow[b]{2}{*}{$-0,38$} & \\
\hline & kullanabilirlik & Hayır & 139 & 3,20 & 0,81 & 298 & & 0,71 \\
\hline \multirow{6}{*}{ 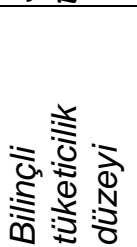 } & Tüketici sorumluluğu & Evet & 161 & 2,87 & 0,53 & \multirow{2}{*}{297} & \multirow{2}{*}{1,15} & \multirow{2}{*}{0,25} \\
\hline & bilinci & Hayır & 138 & 2,80 & 0,52 & & & \\
\hline & Kalite bilinci & Evet & 160 & 3,03 & 0,57 & \multirow{2}{*}{297} & \multirow{2}{*}{$-0,24$} & \multirow{2}{*}{0,81} \\
\hline & & Hayır & 139 & 3,04 & 0,52 & & & \\
\hline & Bütce-fiyat bilinci & Evet & 161 & 3,32 & 0,52 & \multirow{2}{*}{298} & \multirow{2}{*}{0,47} & \multirow{2}{*}{0,64} \\
\hline & & Hayır & 139 & 3,30 & 0,51 & & & \\
\hline
\end{tabular}


Polat, E. ve Kır, S. (2020). Spor Bilimleri Öğrencileri ve Diğer Bireylerde Bilinçli Tüketicilik Düzeyi İle Sürdürülebilir Tüketim Davranışlarının İncelenmesi. Gaziantep Üniversitesi Spor Bilimleri Dergisi, 5(4), 468485.

Tablo 7'de katııımcıların rekreatif spor yapma durumlarına göre sürdürülebilir tüketim davranışları ölçeği ve bilinçli tüketicilik düzeyi ölçeği alt boyutları arasındaki farkılıılar incelenmiştir. Tabloya göre sürdürülebilir tüketim davranışları ölçeğinin ihtiyaç dışı satın alma alt boyutunda rekreatif spor yapmayanların lehine anlamlı farklılıklar $(p<0,05)$ tespit edilmiştir. Diğer alt boyutlarda ise anlamlı farklıık bulunmamaktadır.

Tablo 8. Demografik Değişkenler Ille Sürdürülebilir Tüketim Davranışları ve Bilinçli Tüketicilik Düzeyi Alt Boyutları Arasındaki Ilişkiler

\begin{tabular}{|c|c|c|c|c|c|}
\hline & Yaş & Gelir (TL) & $\begin{array}{c}\text { Akademik } \\
\text { başarı }\end{array}$ & $\begin{array}{c}\text { Spor } \\
\text { süresi }\end{array}$ & $\begin{array}{c}\text { Doğaya } \\
\text { duyarlılık }\end{array}$ \\
\hline Çevre duyarlıı̆̆ı & 0,03 & 0,10 & $0,12^{*}$ & $0,15^{\star *}$ & $0,34^{\star *}$ \\
\hline İhtiyaç dışı satın alma & $-0,02$ & $0,19 * *$ & $-0,11$ & 0,11 & $-0,09$ \\
\hline Tasarruf & 0,05 & 0,10 & $0,13^{*}$ & 0,09 & 0,11 \\
\hline Yeniden kullanabilirlik & 0,10 & $0,12^{*}$ & 0,07 & 0,12 & $0,19 * *$ \\
\hline Tüketici sorumluluğu bilinci & 0,10 & 0,06 & $0,17^{\star *}$ & 0,05 & $0,17^{* *}$ \\
\hline Kalite bilinci & 0,05 & 0,05 & 0,04 & 0,09 & $0,12^{*}$ \\
\hline Bütçe-fiyat bilinci & 0,02 & $-0,04$ & 0,09 & $-0,07$ & 0,07 \\
\hline
\end{tabular}

Tablo 8'dedemografik değişkenler (yaş, gelir, akademik başarı, spor süresi, doğaya duyarlıık) ile sürdürülebilir tüketim davranışları ve bilinçli tüketicilik düzeyi alt boyutları arasındaki ilişkiler incelenmiştir. Bulgulara göre Çevre duyarıı̆ı̆ı ile Akademik başarı, Spor yapma süresi ve doğaya duyarlııı arasında pozitif yönde zayıf düzeyde ilişki bulunmaktadır. İhtiyaç dışı satın alma ve gelir arasında pozitif yönde zayıf düzeyde ilişki vardır. Tasarruf ve Akademik başarı arasında pozitif yönde zayıf düzeyde ilişki bulunmaktadır. Yeniden kullanabilirlik ile Gelir ve Doğaya duyarlılık arasında pozitif yönde zayıf düzeyde ilişki bulunmaktadır. Tüketici sorumluluğu bilinci ile Akademik başarı ve Doğaya duyarlılık arasında pozitif yönde zayıf düzeyde ilişki bulunmaktadır. Yaş ve ölçek alt boyutları arasında hiçbir ilişki görülmemiştir. Diğer alt boyutlarda ise anlamlı farklıık bulunmamaktadır.

Tablo 9. Sürdürülebilir Tüketim Davranışları ve Bilinçli Tüketicilik Düzeyi Alt Boyutları Arasındaki Ilişkiler

\begin{tabular}{lccc}
\hline & $\begin{array}{c}\text { Tüketici sorumluluğu } \\
\text { bilinci }\end{array}$ & Kalite bilinci & Bütçe-fiyat bilinci \\
\hline Çevre duyarılı̆̆ı & $\mathbf{0 , 3 3 ^ { * * }}$ & $\mathbf{0 , 1 7 ^ { * * }}$ & $\mathbf{0 , 1 6 ^ { * * }}$ \\
İhtiyaç dışı satın alma & $-\mathbf{0 , 2 3 ^ { * * }}$ & $\mathbf{0 , 1 4 ^ { * }}$ & $-\mathbf{0 , 4 3}$ \\
Tasarruf & $\mathbf{0 , 4 1 ^ { * * }}$ & $\mathbf{0 , 2 0 ^ { * * }}$ & $\mathbf{0 , 1 6 ^ { * * }}$ \\
Yeniden kullanabilirlik & $\mathbf{0 , 3 8 ^ { * * }}$ & $\mathbf{0 , 1 8 ^ { * * }}$ & $\mathbf{0 , 3 1 ^ { * * }}$ \\
\hline \multicolumn{1}{c}{$\mathrm{N}=299-300 \quad{ }^{*} \mathrm{p}<0,05$} & ${ }^{* \star} \mathrm{p}<0,01$ & &
\end{tabular}


Tablo 9 incelendiğinde STD ve BTD ölçek alt boyutları arasında pozitif yönde anlamlı ilişki bulunmaktadır. İhtiyaç dışı satın alma ile Tüketici sorumluluğu bilince ve bütçefiyat bilinci arasında negatif yönde anlamlı bir ilişki bulunurken; Kalite bilinciyle ise pozitif yönde anlamlı bir ilişki bulunmaktadır. Tasarruf ve Yeniden kullanabilirlik boyutları ile Tüketici sorumluluğu bilinci boyutları arasında diğer ilişkilere nazaran daha güçlü ilişkiler bulunmaktadır.

Tablo 10. Eğitim Bölümüne Göre Sürdürülebilir Tüketim Davranışları ve Bilinçli Tüketicilik Düzeyi Alt Boyut Korelasyonları Arasındaki Farklar

\begin{tabular}{|c|c|c|c|c|c|c|c|c|}
\hline \multirow[t]{2}{*}{ Alt Boyutlar } & \multirow[t]{2}{*}{ Bölüm } & \multirow[b]{2}{*}{$\mathbf{n}$} & \multicolumn{2}{|c|}{$\begin{array}{c}\text { Tüketici } \\
\text { sorumluluğu bilinci }\end{array}$} & \multicolumn{2}{|c|}{ Kalite bilinci } & \multicolumn{2}{|c|}{$\begin{array}{l}\text { Bütçe-fiyat } \\
\text { bilinci }\end{array}$} \\
\hline & & & $r$ & z & $r$ & $z$ & $r$ & z \\
\hline $\begin{array}{l}\text { Çevre } \\
\text { duyarlılığı }\end{array}$ & $\begin{array}{l}\text { Spor Bilimleri } \\
\text { Diğer Bölümler }\end{array}$ & $\begin{array}{l}147 \\
153\end{array}$ & $\begin{array}{l}0,31^{\star *} \\
0,35^{\star *}\end{array}$ & $-0,39$ & $\begin{array}{l}0,17^{*} \\
0,19^{*}\end{array}$ & $0,-$ & $\begin{array}{l}0,15 \\
0,18^{*}\end{array}$ & $-0,26$ \\
\hline $\begin{array}{l}\text { İhtiyaç dışı } \\
\text { satın alma }\end{array}$ & $\begin{array}{l}\text { Spor Bilimleri } \\
\text { Diğer Bölümler }\end{array}$ & $\begin{array}{l}147 \\
153\end{array}$ & $\begin{array}{c}-0,15 \\
-0,30^{\star *}\end{array}$ & 1,36 & $\begin{array}{c}0,03 \\
0,25^{\star \star}\end{array}$ & $\overline{-}$ & $\begin{array}{l}-0,36^{\star *} \\
-0,49^{\star *}\end{array}$ & $-1,36$ \\
\hline Tasarruf & $\begin{array}{l}\text { Spor Bilimleri } \\
\text { Diğer Bölümler }\end{array}$ & $\begin{array}{l}147 \\
153\end{array}$ & $\begin{array}{l}0,43^{* *} \\
0,40^{* *}\end{array}$ & 0,31 & $\begin{array}{c}0,15 \\
0,28^{\star \star}\end{array}$ & $\overline{1,17}$ & $\begin{array}{l}0,17^{\star} \\
0,15\end{array}$ & 0,18 \\
\hline $\begin{array}{l}\text { Yeniden } \\
\text { kullanabilirlik }\end{array}$ & $\begin{array}{l}\text { Spor Bilimleri } \\
\text { Diğer Bölümler }\end{array}$ & $\begin{array}{l}147 \\
153\end{array}$ & $\begin{array}{l}0,43^{\star *} \\
0,34^{\star *}\end{array}$ & 0,91 & $\begin{array}{c}0,25^{\star *} \\
0,07\end{array}$ & 1,59 & $\begin{array}{l}0,33^{\star *} \\
0,28 * \star\end{array}$ & 0,47 \\
\hline
\end{tabular}

Tablo 10'da spor bilimleri ve diğer bölümlerde eğitim gören öğrenciler olmak üzere iki gruba ayrılan bölüm değişkenine göre gruplar oluşturularak STD ve BTD alt boyutları arasındaki korelasyonlar tespit edilmiştir. Belirlenen korelasyon değerlerinin z skorları alınarak spor bilimleri ve diğer bölümler arasındaki $r$ değeri farklııkları incelenmiştir. Elde edilen bulgulara göre; her iki ölçeğin alt boyutları arasında bölüm değişkeni çerçevesinde anlamlı farklılık oluşturacak düzeyde korelasyonlar oluşmamıştır. Özetle sürdürülebilir tüketim davranışları ve bilinçli Tüketicilik düzeyi alt boyutlarına ilişkin korelasyonlar arasında spor bilimleri ve diğer bölümlerde eğitim gören öğrenciler açısından istatistiksel olarak anlamlı sayılacak herhangi bir farklılaşma yoktur. 
Polat, E. ve Kır, S. (2020). Spor Bilimleri Öğrencileri ve Diğer Bireylerde Bilinçli Tüketicilik Düzeyi İle Sürdürülebilir Tüketim Davranışlarının İncelenmesi. Gaziantep Üniversitesi Spor Bilimleri Dergisi, 5(4), 468485.

Tablo 11. Lisans Durumuna Göre Sürdürülebilir Tüketim Davranışları ve Bilinçli Tüketicilik Düzeyi Alt Boyut Korelasyonları Arasındaki Farklar

\begin{tabular}{|c|c|c|c|c|c|c|c|c|}
\hline \multirow[t]{2}{*}{ Alt Boyutlar } & \multirow[t]{2}{*}{$\begin{array}{l}\text { Lisanslı } \\
\text { Sporcu }\end{array}$} & \multirow[b]{2}{*}{$\mathbf{n}$} & \multicolumn{2}{|c|}{$\begin{array}{c}\text { Tüketici } \\
\text { sorumluluğu bilinci }\end{array}$} & \multicolumn{2}{|c|}{ Kalite bilinci } & \multicolumn{2}{|c|}{$\begin{array}{l}\text { Bütçe-fiyat } \\
\text { bilinci }\end{array}$} \\
\hline & & & $r$ & z & $r$ & $\mathbf{z}$ & $r$ & z \\
\hline Çevre duyarlılığı & $\begin{array}{l}\text { Evet } \\
\text { Hayır }\end{array}$ & $\begin{array}{c}57 \\
242\end{array}$ & $\begin{array}{l}0,30^{\star} \\
0,34^{\star \star}\end{array}$ & $-0,30$ & $\begin{array}{c}0,14 \\
0,18^{\star *}\end{array}$ & $-0,27$ & $\begin{array}{l}0,10 \\
0,19 * \star\end{array}$ & $-0,61$ \\
\hline $\begin{array}{l}\text { İhtiyaç dışı satın } \\
\text { alma }\end{array}$ & $\begin{array}{l}\text { Evet } \\
\text { Hayır }\end{array}$ & $\begin{array}{c}57 \\
242\end{array}$ & $\begin{array}{c}-0,21 \\
-0,24^{\star *}\end{array}$ & 0,21 & $\begin{array}{c}0,02 \\
0,17^{\star *}\end{array}$ & $-1,01$ & $\begin{array}{l}-0,47^{\star *} \\
-0,41^{\star *}\end{array}$ & $-0,49$ \\
\hline Tasarruf & $\begin{array}{l}\text { Evet } \\
\text { Hayır }\end{array}$ & $\begin{array}{c}57 \\
242\end{array}$ & $\begin{array}{l}0,29 * \\
0,50 \text { ** }\end{array}$ & $-1,66^{*}$ & $\begin{array}{c}0,00 \\
0,29 * *\end{array}$ & $-1,98^{*}$ & $\begin{array}{c}0,06 \\
0,23^{\star \star}\end{array}$ & $-1,16$ \\
\hline $\begin{array}{l}\text { Yeniden } \\
\text { kullanabilirlik }\end{array}$ & $\begin{array}{l}\text { Evet } \\
\text { Hayır }\end{array}$ & $\begin{array}{c}57 \\
242\end{array}$ & $\begin{array}{l}0,44^{\star *} \\
0,38^{\star \star}\end{array}$ & 0,48 & $\begin{array}{c}0,01 \\
0,21^{* *}\end{array}$ & $-1,35$ & $\begin{array}{c}0,24 \\
0,34^{\star \star}\end{array}$ & $-0,73$ \\
\hline
\end{tabular}

Tablo 11'de lisans durumu temel alınarak STD ve BTD alt boyutları arasındaki korelasyonlar belirlenmiş ve ortaya çıkan korelasyon değerlerinin z skorları alınarak lisans durumu arasındaki $r$ değeri farklılıkları incelenmiştir. Sonuçlara göre tüketici sorumluluğu bilinci ve tasarruf ile kalite bilinci ve tasarruf arasındaki korelasyonlar lisanslı sporcu olmayanlar lehine anlamlı olarak daha yüksek olduğu belirlenmiştir. İki ölçeğe ilişkin sporculuk durumu dikkate alınarak diğer boyutlar arası yapılan korelasyonlarda ise anlamlı bir farklılık oluşmamıştır.

Tablo 12. Rekreatif Spor Yapma Durumuna Göre Sürdürülebilir Tüketim Davranışları ve Bilinçli Tüketicilik Düzeyi Alt Boyut Korelasyonları Arasındaki Farklar

\begin{tabular}{|c|c|c|c|c|c|c|c|c|}
\hline \multirow[t]{2}{*}{ Alt Boyutlar } & \multirow[t]{2}{*}{$\begin{array}{l}\text { Rekreatif } \\
\text { Spor }\end{array}$} & \multirow[b]{2}{*}{$\mathbf{n}$} & \multicolumn{2}{|c|}{$\begin{array}{l}\text { Tüketici sorumluluğu } \\
\text { bilinci }\end{array}$} & \multicolumn{2}{|c|}{ Kalite bilinci } & \multicolumn{2}{|c|}{$\begin{array}{l}\text { Bütçe-fiyat } \\
\text { bilinci }\end{array}$} \\
\hline & & & $r$ & z & $r$ & $z$ & $r$ & z \\
\hline Çevre duyarlııı̆ı & $\begin{array}{l}\text { Evet } \\
\text { Hayır }\end{array}$ & $\begin{array}{l}161 \\
139\end{array}$ & $\begin{array}{l}0,35^{\star *} \\
0,30^{\star *}\end{array}$ & 0,48 & $\begin{array}{c}0,13 \\
0,24^{\star *}\end{array}$ & $-0,98$ & $\begin{array}{l}0,12 \\
0,21^{*}\end{array}$ & $-0,79$ \\
\hline $\begin{array}{l}\text { İhtiyaç dışı satın } \\
\text { alma }\end{array}$ & $\begin{array}{l}\text { Evet } \\
\text { Hayır }\end{array}$ & $\begin{array}{l}161 \\
139\end{array}$ & $\begin{array}{c}-0,33^{\star *} \\
-0,11\end{array}$ & $-1,99$ & $\begin{array}{c}0,38 \\
0,26^{* *}\end{array}$ & 1,15 & $\begin{array}{c}-0,38^{\star *} \\
0,48^{\star *}\end{array}$ & $-0,89$ \\
\hline Tasarruf & $\begin{array}{l}\text { Evet } \\
\text { Hayır }\end{array}$ & $\begin{array}{l}161 \\
139\end{array}$ & $\begin{array}{l}0,43^{* *} \\
0,38^{\star *}\end{array}$ & 0,38 & $\begin{array}{c}0,13 \\
0,33^{* *}\end{array}$ & $-1,81$ & $\begin{array}{c}0,12 \\
0,22^{\star *}\end{array}$ & $-0,88$ \\
\hline $\begin{array}{l}\text { Yeniden } \\
\text { kullanabilirlik }\end{array}$ & $\begin{array}{l}\text { Evet } \\
\text { Hayır }\end{array}$ & $\begin{array}{l}161 \\
139\end{array}$ & $\begin{array}{l}0,44^{* *} \\
0,31^{\star *}\end{array}$ & 1,30 & $\begin{array}{c}0,21^{* *} \\
0,12\end{array}$ & 0,79 & $\begin{array}{l}0,34^{*} \\
0,27^{\star *}\end{array}$ & 0,66 \\
\hline
\end{tabular}

${ }^{*} \mathrm{p}<0,05 \quad{ }^{\star \star} \mathrm{p}<0,01$

Tablo 12'de yapılan rekreatif spor yapma durumuna göre gruplar oluşturularak STD ve BTD alt boyutları arasındaki korelasyonlar tespit edilmiştir. Belirlenen korelasyon değerlerinin z skorları alınarak rekreatif spor yapanlar ve yapmayanlar arasındaki $r$ değeri farklılıkları incelenmiştir. Elde edilen bulgulara göre; rekreatif amaçlı spor yapanlar ve yapmayanlar açısından her iki ölçeğe ait alt boyutlar arası korelasyonel ilişkilerde istatistiksel açıdan herhangi bir anlamlı farklılık bulunmamıştır. 
Polat, E. ve Kır, S. (2020). Spor Bilimleri Öğrencileri ve Diğer Bireylerde Bilinçli Tüketicilik Düzeyi İle Sürdürülebilir Tüketim Davranışlarının İncelenmesi. Gaziantep Üniversitesi Spor Bilimleri Dergisi, 5(4), 468485.

\section{Tartışma ve Sonuç}

Evrende tükenebilir kaynaklara sahip olmamız ve bu kaynakları nasıl kullanılacağımızın bilinmemesi günümüz sorunları arasında büyük önem taşımaktadır. Bireylerin tüketici olarak, ihtiyaçlarını karşılayabilmek, yaşam standartlarını koruyabilmek için var olan kaynakları kullanmada bilinçli olmaları gerekmektedir. Bu nedenle bireylere tüketici eğitimi verilmesi gerekmektedir. Tüketici eğitimi; bireylerin ihtiyaçlarını belirleme, tüketimden maksimum yarar sağlanma, karar verme bilinçlerinin artmasına ve değişen ekonomiyi anlamasına yardımcı olmaktır (Bayazıt Hayta, 2009).

$\mathrm{Bu}$ araştırma ile spor bilimleri öğrencileri ve diğer bireylerde bilinçli tüketicilik düzeyi ile sürdürülebilir tüketim davranışları incelenmiştir. Bunu yanı sıra öğrencilerin; yaş, cinsiyet, gelir düzeyi, akademik başarı ortalaması, eğitim görülen fakülte/yüksekokul, lisans durumu, rekreatif amaçlı spor yapma durumu, doğanın korunmasına karşı duyarlılık düzeylerinin anlamlı bir fark gösterip göstermediği araştırılmıştır.

Elde edilen bulgulara göre ölçeklerin alt boyutlarından sürdürülebilir tüketim davranışları ölçeğinin ihtiyaç dışı satın alma alt boyutunun kadınların lehine anlamlı farklılık gösterdiği tespit edilmiştir. Bilinçli tüketicilik düzeyi ile cinsiyet değişkeni arasında ise anlamlı fark bulunmamaktadır(Tablo 4). Çelebi'nin (2019) yaptığı çalışmasında sekizinci sınıf öğrencilerinin, cinsiyet değişkenine göre bilinçli tüketicilik düzeylerinde anlamlı bir fark bulunmadığı belirtilmiştir. Malbeleği'nin (2011) yaptığı çalışmasında ilköğretim 4. sınıf öğrencilerinin bilinçli tüketicilik düzeylerinin cinsiyet değişkenine göre farklılık göstermediğini belirtmektedir. Aynı şekilde Alimcan (2018) ile Polat ve Ünişen (2016), bilinçli tüketicilik düzeyi ile cinsiyet değişkeni arasında anlamlı bir farklılık bulunmadığını belirtmişlerdir. Ancak yapılan taramalardaki bazı araştırmalarda ise, cinsiyet değişkenine göre bilinçli tüketicilik düzeyi erkek öğrencilere kıyasla kız öğrencilerin daha yüksek olduğu görülmüştür. Dursun (1993), yaptığı çalışmasında, kızların erkeklere kıyasla ebeveynleri ile daha sık alış-veriş yaptıkları için tüketime yönelik daha olumlu düşüncelere sahip olduğunu belirtmiştir. Özkaya (2013) yaptığı çalışmasında, kız öğrencilerin erkek öğrencilere göre tüketicilik konusunda daha bilinçli olduklarını belirlemiştir. Genel olarak araştırma bulgularını değerlendirdiğimizde bilinçli tüketicilik düzeyi ile cinsiyet değişkeni arasında bir fark bulunmamakta ancak kız çocuklarının aile içerisinde tüketim 
Polat, E. ve Kır, S. (2020). Spor Bilimleri Öğrencileri ve Diğer Bireylerde Bilinçli Tüketicilik Düzeyi İle Sürdürülebilir Tüketim Davranışlarının İncelenmesi. Gaziantep Üniversitesi Spor Bilimleri Dergisi, 5(4), 468485.

faaliyetlerine erkek çocuklarına oranla daha erken tanışmalarından ötürü bilinçli tüketicilik düzeylerinin daha yüksek olduğunu gösteren çalışmaların bulunduğu söylenebilir. Bununla birlikte kadınların erkeklere oranla daha çok alışveriş eğilimli oldukları ve satın alma davranışını da sıklıkla gerçekleştirdikleri genel anlamda bilinen bir gerçektir. Bu durum kadınlar lehine gereksiz yani intiyaç dışı satın alma davranışını tetiklemiş olabileceğini düşündürtmüştür.

Ölçek alt boyutları ile bölüm arasında herhangi bir fark bulunmazken (Tablo 5), sürdürülebilir tüketim davranışları ölçeğinin çevre duyarlıı̆̆ı lisanslı sporcuların lehine ve intiyaç dışı satın alma alt boyutlarında lisanslı sporcular ve rekreatif spor yapmayan bireylerin lehine anlamlı farklııkların olduğu görülmektedir. (Tablo 6- Tablo 7). İhtiyaç dışı satın alma davranışına ilişkin lisanslı sporcular üzerine elde edilmiş bu sonuç oldukça manidar olarak değerlendirilmekle birlikte, gelecek araştırmalarda benzer sonuçların karşılaştıılarak elde edilen bulgunun tutarlıık gücünün sorgulanması gerektiği düşünülmüştür. Yine bu sonuçlar doğrultusunda lisanslı spor yapan bireylerin çevresel hassasiyete daha fazla önem verdiği, ihtiyaç dışı satın alma davranışlarının ise lisanslı spor yapan ve rekreatif spor yapmayan bireylerde olduğu görülmektedir. Polat ve ark., (2019) yapmış oldukları çalışmalarında lisanslı sporcuların sürdürülebilir tüketim davranışlarının ölçek alt boyutlarında sedanterlere göre daha iyi olduğunu, rekreatif amaçlı fiziksel aktiviteye dâhil olan kişilerin katılmayan kişilere kıyasla daha iyi oranda sürdürülebilir tüketim alışkanlıklarının olduğu belirtmişlerdir. Her iki çalışma da göstermektedir ki bir eğitim aracı olan ve bireyde çok çeşitli etkilere sahip olan spor olgusu aynı zamanda kişinin çevreye olan duyarlıı̆ını arttırabilmektedir.

Sürdürülebilir tüketim davranışları ve Bilinçli tüketicilik düzeyleri ölçek alt boyutları arasındaki ilişkiler incelendiğinde; intiyaç dışı satın alma ile tüketici sorumluluğu bilince ve bütçe-fiyat bilinci arasında negatif yönde anlamlı bir ilişki bulunurken; kalite bilinciyle ise pozitif yönde anlamlı bir ilişki bulunmaktadır. Tasarruf ve yeniden kullanabilirlik boyutları ile Tüketici sorumluluğu bilinci arttıkça daha güçlü bir ilişki bulunmaktadır (Tablo 9). Bu sonuçlara göre; tüketici sorumluluğu bilinci ve bütçe- fiyat bilinci olanlar intiyaç dışı satın alma davranışı göstermemektedir. Bilinç artıkça intiyaç dışı satın alma davranışı azalırken, kalite bilinci artıkça intiyaç dışı satın alma davranışı da artış göstermektedir. 
Polat, E. ve Kır, S. (2020). Spor Bilimleri Öğrencileri ve Diğer Bireylerde Bilinçli Tüketicilik Düzeyi İle Sürdürülebilir Tüketim Davranışlarının İncelenmesi. Gaziantep Üniversitesi Spor Bilimleri Dergisi, 5(4), 468485.

Sürdürülebilir tüketim davranışları ve bilinçli Tüketicilik düzeyi alt boyutlarına ilişkin korelasyonlar arasında spor bilimleri ve diğer bölümlerde eğitim gören öğrenciler açısından istatistiksel olarak anlamlı sayılacak herhangi bir farklılaşma yoktur (Tablo 10). Araştırmadan elde edilen bu bulgunun nedeni çalışmaya katılan bireylerin bulunduğu çevresel koşullardan kaynaklanabilir.

Lisans durumu temel alınarak STD ve BTD alt boyutları arasındaki korelasyonlar belirlenmiş tüketici sorumluluğu bilinci ve tasarruf ile kalite bilinci ve tasarruf arasındaki korelasyonlar lisanslı sporcu olmayanlar lehine anlamlı olarak daha yüksek olduğu belirlenmiştir. İki ölçeğe ilişkin sporculuk durumu dikkate alınarak diğer boyutlar arası yapılan korelasyonlarda ise anlamlı bir farklılık oluşmamıştır (Tablo 11). Sporculuk durumu ölçek alt boyutları arasında fark bulunmamasına karşın yapılan alan yazın taramasında sporun birçok faktör üzerinde etkili olduğu görülmektedir. Örneğin; Canan ve Ataoğlu (2010) yapmış oldukları çalışmada düzenli spor yapmanın anksiyete belirtileri üzerine olumlu etkisi olduğunu ortaya koymuştur. Yapılan rekreatif spor yapma durumuna göre rekreatif amaçlı spor yapanlar ve yapmayanlar açısından her iki ölçeğe ait alt boyutlar arası korelasyonel ilişkilerde istatistiksel açıdan herhangi bir anlamlı farklılık bulunmamıştır (Tablo 12). Çalışmamızın aksine rekreatif amaçlı yapılan fiziksel aktivitelerin kişide birçok gelişime katkı sağladığı görülmektedir. Örneğin, Ardahan ve Lapa (2011) yapmış oldukları çalışmada, doğa etkinliklerine katılan bireylerin rahatlamış, hafiflemiş, daha mutlu ve sağlıkı hissettiklerini, bu tarz etkinlikler ile birlikte kişilerin öz güvenleri ve hayal güçlerini artmakta, çevre bilinci oluşmakta, öğrenmeye ve yeni kişilerle tanışmaya açık hissetmekte olduklarını belirtmişlerdir. Araştırma sonucunda elde edilen bulgulara göre bilinçli tüketicilik düzeyi sürdürülebilir tüketim davranışlarını etkilediği söylenebilir.

\section{Öneriler}

Sporun sürdürülebilir tüketim ve bilinçli tüketicilik düzeyi üzerindeki etkileri değerlendirilerek olumlu olan etkenlerin bireylere spor eğitimi yoluyla aktarılması sağlanabilir. Sürdürülebilir tüketim alışkanlığı ve tüketim bilincinin geliştirilmesinde sporcular rol model olarak kullanılabilir. Farklı örneklemler üzerinden konunu ile bağlantılı yeni araştırmalar yapılarak elde edilen bulguların daha güçlü bir zemine oturtulması sağlanabilir. 


\section{Kaynaklar}

Aksu, C., K. (2014). Üniversite çalışanlarının sürdürülebilir tüketime yönelik tutumlarının belirlenmesi: Kafkas üniversitesi örneği. Yüksek Lisans Tezi, Kafkas Üniversitesi, Sosyal Bilimleri Enstitüsü, İşletme Anabilim Dalı, Kars.

Akyüz, Z. (2009). İlköğretim Çağındaki öğrencilerin tüketim davranışları ve tüketicilik bilinç düzeyi. Yüksek Lisans Tezi, Gazi Üniversitesi, Eğitim Bilimleri Enstitüsü, Ankara.

Alimcan, D. (2018). Ortaokul öğrencilerinin bilinçli tüketicilik düzeylerinin çeşitli değişkenler açısından incelenmesi: Amasya İli Örneği. Yüksek Lisans Tezi, Amasya Üniversitesi, Sosyal Bilimler Enstitüsü, Türkçe ve Sosyal Bilimler Anabilim Dalı, Amasya.

Ardahan, F., \& Yerlisu Lapa, T. (2010). Açık alan rekreasyonu: Bisiklet kullanıcıları ve yürüyüşçülerin doğa sporu yapma nedenleri ve elde ettikleri faydalar. Uluslararası Insan Bilimleri Dergisi, 8(1), 1327-1341.

Aysel, A. (2018). Kuşakların tüketim davranışlarında değişim üzerine bir inceleme. Yüksek Lisans Tezi, Kocaeli Üniversitesi, Sosyal Bilimler Enstitüsü, Halkla İlişkiler ve Tanıtım Anabilim Dalı, Kocaeli.

Bayazıt Hayta, A. (2009). Sürdürülebilir tüketim davranışının kazanılmasında tüketici eğitiminin rolü. Ahi Evran Üniversitesi Kırşehir Eğitim Fakültesi Dergisi, 10(3), 143-151.

Burucuoğlu, M. (2016). Tüketicilerin etik pozisyonu, tüketim değerleri ve sorumlu tüketim davranışları arasındaki ilişkiler üzerine bir araştırma. Doktora Tezi, Ondokuz Mayıs Üniversitesi, Sosyal Bilimler Enstitüsü, İşletme Anabilim Dalı, Samsun.

Canan, F., \& Ataoğlu, A. (2010). Anksiyete, depresyon ve problem çözme becerisi algısı üzerine düzenli sporun etkisi. Anadolu Psikiyatri Dergisi, 11:38-43

Chang, H. H. (2017). Consumer socially sustainable consumption: the perspective toward corporate social responsibility, perceived value, and brand loyalty. Journal of Economics and Management, 13(2), 167-191.

Çelebi, F. (2019). 8. Sınıf öğrencilerinin bilinçli tüketicilik düzeyleri ile çevreye yönelik tutumları arasındaki ilişkinin incelenmesi: Denizli İli Örneği Yüksek Lisans Tezi, Pamukkale Üniversitesi, Eğitim Bilimleri Enstitüsü, Türkçe ve Sosyal Bilimler Eğitimi Anabilim Dalı, Denizli. 
Çelik, N. (2013). Thorstein Veblen'in gösterişçi tüketim yaklaşımı: Niğde Üniversitesi İdari Personeli Örneği. Erciyes Üniversitesi Sosyal Bilimler Enstitüsü Dergisi, 33(1), 171-203 .

Diksaç, R. (2019). Çevre bilinci ve yaşam tarzının sürdürülebilir tüketim davranışı üzerindeki etkisi ve bir araştırma. Yüksek Lisans Tezi, Marmara Üniversitesi, Sosyal Bilimler Enstitüsü, İşletme Anabilim Dalı. İstanbul.

Doğan, O., Bulut, Z. A., \& Kökalan Çımrın, F. (2015). Bireylerin sürdürülebilir tüketim davranışlarının ölçülmesine yönelik bir ölçek geliştirme çalışması. Atatürk Üniversitesi Iktisadi ve Idari Bilimler Dergisi, 29(4), 659-678.

Dursun, Y. (1993). Gençlerin tüketicilik rolünü kazanmaları. Doktora Tezi, Erciyes Üniversitesi, Sosyal Bilimler Enstitüsü, Kayseri.

Garip, S. (2019). Demografik özelliklerin tüketici karar verme tarzları ve sürdürülebilir tüketim davranışına etkisi. Yüksek Lisans Tezi, Ege Üniversitesi, Sosyal Bilimler Enstitüsü, Halkla İlişkiler ve Tanıtım Anabilim Dalı, İzmir.

Gülmez, M. (2006). Pazarlama yönü itibariyle bilinçli tüketim ve bilinçli tüketiciye ilişkin bir saha araştırması. Selçuk Üniversitesi Sosyal Bilimler Meslek Yüksekokulu Dergisi, 9(1- 2), 153-178.

Hoq, K. M. R. (2017). Users motivation to take part in the sharing economy in Turkey: A chaperone to sustainable consumption / Türkiye'de paylaşım ekonomisine katılma motivasyonu: Sürdürülebilir tüketim için bir yol (Yüksek Lisans Tezi). Marmara Üniversitesi, Sosyal Bilimler Enstitüsü, İşletme (İngilizce) Anabilim Dalı, İstanbul.

Hürmeriç, P. \& Baban, E. (2012). Simmel, Veblen ve Sombart'ın penceresinden hedonik tüketim: Ütopyada Negotıum ve Otıum, Global Media Journal: Turkısh Editıon 2(4), 91.

Karalar, R., Erdoğan, B. Z., \& Kiracı, H. (2008). Çevreye ilişkin bilgi düzeyi ve sürdürülebilir tüketim davranışı ilişkisi: üniversite öğrencileri üzerinde bir uygulama. 13. Ulusal Pazarlama Kongresi. Adana.

Karalar, R., \& Kiracı, H. (2011). Çevresel sorunlara karşı bir çözüm önerisi olarak sürdürülebilir tüketim düşüncesi. Dumlupınar Üniversitesi Sosyal Bilimler Enstitüsü Dergisi, 30, 63-76.

Karasar, N. (2016). Bilimsel Araştırma Yöntemi: Kavramlar Illkeler ve Teknikler. 31. Basım Ankara: Nobel Akademik Yayınclık. 
Polat, E. ve Kır, S. (2020). Spor Bilimleri Öğrencileri ve Diğer Bireylerde Bilinçli Tüketicilik Düzeyi İle Sürdürülebilir Tüketim Davranışlarının İncelenmesi. Gaziantep Üniversitesi Spor Bilimleri Dergisi, 5(4), 468485.

Malbeleği, F. (2011). Drama yönetiminin sosyal bilgiler dersi başarısına ve bilinçli tüketicilik düzeyine etkisi. Yüksek Lisans Tezi, Sakarya Üniversitesi, Eğitim Bilimleri Enstitüsü, İlköğretim Anabilim Dalı, Sakarya.

Narman, Z. (2018). Üniversite öğrencilerinin tüketim davranışları analizi: Kocaeli Üniversitesi Örneği. Yüksek Lisans Tezi, Kocaeli Üniversitesi, Sosyal Bilimler Enstitüsü, İktisat Anabilim Dalı, Kocaeli.

OECD (2008). Promoting sustainable consumption: Good practising in OECD contries. Usa, OECD Publishing. https://www.oecd.org/ greengrowth/ 40317373.pdf, (Erişim: 11.11.2020)

Özkaya, O. (2013). Illköğretim ikinci kademe öğrencilerinin tüketici eğitim konusundaki bilgi ve tutumlarının incelenmesi. Yüksek Lisans Tezi, Gazi Üniversitesi, Eğitim Bilimleri Enstitüsü, Ankara.

Özkul, F., \& Tapşın, G . (2010). Kredi kartı kullanımı ile kullanılabilir gelirin tüketim üzerindeki etkisi ve Türkiye ekonomisi üzerine bir ampirik çalışma. Muhasebe ve Finansman Dergisi, (47), 138-153.

Polat, E., Akoğlu, H., Konak, O., \& Özen, G. (2019). Fiziksel aktivite yapan ve yapmayan bireylerde sürdürülebilir tüketim davranışlarının incelenmesi. Spormetre Beden Eğitimi ve Spor Bilimleri Dergisi, 17(2) , 53- 63.

Polat, H., \& Ünişen, A. (2016). Ebeveyn görüşlerine göre hayat bilgisi eğitimini almış çocuklarının bilinçli tüketici olma durumları. Eğitimde Kuram ve Uygulama, 12 (3), 670-694 .

Robinson, R., \& Smith, C. (2003). Associations between self-reported health conscious consumerism, body-mass index, and attitudes about sustainably produced foods. Agriculture and Human Values, 20(2), 177-187.

Saba, C. (2019), Sürdürülebilir tüketim bağlamında yeşil tüketim. Doktora Tezi, Ankara Üniversitesi, Sosyal Bilimler Enstitüsü, Sosyal Çevre Bilimleri Anabilim Dalı, Ankara.

Sağlam, H. İ. (2010). Bilinçli tüketicilik düzeyi ölçeği çalışması, International Journal of Human Sciences, 7(1), 1190-2000.

Şart, G. (2019). Sürdürülebilirlik Nedir? Sürdürülebilir Kalkınmanın 17 Küresel Hedefi. "https://gamzesart.com/2020/02/21/surdurulebilirlik-nedir-surdurulebilirkalkinmanin- 17-kuresel-hedefi/" (Erişim Tarihi: 05.05.2019). 
Polat, E. ve Kır, S. (2020). Spor Bilimleri Öğrencileri ve Diğer Bireylerde Bilinçli Tüketicilik Düzeyi İle Sürdürülebilir Tüketim Davranışlarının İncelenmesi. Gaziantep Üniversitesi Spor Bilimleri Dergisi, 5(4), 468485.

Uyanık, C. (2015). Illkokul 4. sınıf öğrencilerinin bilinçli tüketicilik durumlarının incelenmesi. Yüksek Lisans Tezi, Anadolu Üniversitesi, Eğitim Bilimleri Enstitüsü, İlköğretim Anabilim Dalı, Eskişehir.

Üler, E. (2018). Kadın tüketicilerin tüketim davranışları üzerine amprik bir araştırma. Yüksek Lisans Tezi, Üsküdar Üniversitesi, Sosyal Bilimler Enstitüsü, Nöropazarlama Anabilim Dalı, İstanbul. 